\title{
Review \\ Contribution of PGC-1 $\alpha$ to Obesity- and Caloric Restriction-Related Physiological Changes in White Adipose Tissue
}

\author{
Masaki Kobayashi ${ }^{1, *(\mathbb{D})}$, Yusuke Deguchi ${ }^{1}$, Yuka Nozaki ${ }^{1}$ and Yoshikazu Higami ${ }^{1,2, *}$ \\ 1 Laboratory of Molecular Pathology and Metabolic Disease, Faculty of Pharmaceutical Sciences, \\ Tokyo University of Science, 2641 Yamazaki, Noda 278-8510, Japan; 3B20547@ed.tus.ac.jp (Y.D.); \\ nozaki@rs.tus.ac.jp (Y.N.) \\ 2 Research Institute for Biomedical Sciences, Tokyo University of Science, 2669 Yamazaki, Noda 278-8510, Japan \\ * Correspondence: kobayashim@rs.tus.ac.jp (M.K.); higami@rs.tus.ac.jp (Y.H.); \\ Tel.: +81-4-7121-3676 (M.K. \& Y.H.)
}

Citation: Kobayashi, M.; Deguchi, Y.; Nozaki, Y.; Higami, Y. Contribution of PGC- $1 \alpha$ to Obesity- and Caloric Restriction-Related Physiological Changes in White Adipose Tissue. Int. J. Mol. Sci. 2021, 22, 6025. https:// doi.org/10.3390/ijms22116025

Academic Editors: Gaetano Villani and Elena Piccinin

Received: 28 April 2021

Accepted: 31 May 2021

Published: 2 June 2021

Publisher's Note: MDPI stays neutral with regard to jurisdictional claims in published maps and institutional affiliations.

Copyright: (c) 2021 by the authors. Licensee MDPI, Basel, Switzerland. This article is an open access article distributed under the terms and conditions of the Creative Commons Attribution (CC BY) license (https:// creativecommons.org/licenses/by/ $4.0 /)$.

\begin{abstract}
Peroxisome proliferator-activated receptor $\gamma$ coactivator-1 $\alpha$ (PGC- $1 \alpha)$ regulates mitochondrial DNA replication and mitochondrial gene expression by interacting with several transcription factors. White adipose tissue (WAT) mainly comprises adipocytes that store triglycerides as an energy resource and secrete adipokines. The characteristics of WAT vary in response to systemic and chronic metabolic alterations, including obesity or caloric restriction. Despite a small amount of mitochondria in white adipocytes, accumulated evidence suggests that mitochondria are strongly related to adipocyte-specific functions, such as adipogenesis and lipogenesis, as well as oxidative metabolism for energy supply. Therefore, PGC- $1 \alpha$ is expected to play an important role in WAT. In this review, we provide an overview of the involvement of mitochondria and PGC- $1 \alpha$ with obesityand caloric restriction-related physiological changes in adipocytes and WAT.
\end{abstract}

Keywords: PGC- $1 \alpha$; obesity; caloric restriction; white adipose tissue

\section{Introduction}

Peroxisome proliferator-activated receptor $\gamma(\operatorname{PPAR} \gamma)$ coactivator-1 $\alpha(\mathrm{PGC}-1 \alpha)$ is a master transcriptional cofactor for mitochondrial biogenesis. PGC- $1 \alpha$ was discovered as a PPAR $\gamma$-interacting protein that is expressed preferentially in brown adipose tissue (BAT) [1,2]. PGC-1 $\alpha$ binds to transcription factors, such as nuclear respiratory factor (NRF)-1, NRF-2, and estrogen-related receptor $\alpha(E R R \alpha)$, thereby coactivating downstream genes [3-6]. NRF-1 and NRF-2 transcriptionally regulate various mitochondrial genes involved in the respiratory chain, and replication and transcription of mitochondrial DNA (mtDNA), which encodes part of proteins comprising respiratory chain complexes [5]. ERR $\alpha$ modulates $\beta$-oxidation and the tricarboxylic acid cycle, as well as mitochondrial biogenesis [6-8]. Among the downstream mediators of PGC-1 $\alpha$, transcription factor A mitochondria (TFAM) is a major factor responsible for mitochondrial biogenesis [9]. TFAM coats and stabilizes individual mtDNA molecules and also binds to a specific site of mtDNA, which in turn induces promoter activity during initiation of transcription [10]. Therefore, TFAM is required for replication and transcription of mtDNA. In addition to mitochondrial biogenesis, PGC- $1 \alpha$ is involved in responses to oxidative stress via induction of sirtuin3 (SIRT3), which is a member of the SIRT family. SIRT3 is a deacetylase that localizes within the mitochondrial matrix and plays a pivotal role in $\beta$-oxidation and antioxidative reactions by modulating acetylation levels of mitochondrial enzymes (e.g., long-chain acyl coenzyme A dehydrogenase and manganese superoxide dismutase) [11,12]. PGC-1 $\alpha$ activates transcription of the Sirt3 gene through binding of ERR $\alpha$ to the Sirt3 proximal promoter [13]. These findings suggest that PGC-1 $\alpha$ contributes to not only mitochondrial biogenesis, but also to metabolic pathways and oxidative stress responses. 
Obesity, which is characterized by excess body weight or fat mass due to over-nutrition, causes disturbances in the metabolic, endocrine, and immune systems in the whole body. These obesity-induced abnormalities pose serious health problems, including type 2 diabetes mellitus (T2DM), non-alcoholic fatty liver disease, and cardio- and cerebrovascular diseases [14-16]. Obesity induces many cellular stresses and inflammatory signaling pathways by excess or ectopic accumulation of fat in various tissues, resulting in insulin resistance and hepatic steatosis $[16,17]$. Moreover, emerging evidence has indicated a relationship of mitochondrial dysfunction with oxidative stress and systemic inflammation in the obese condition [18].

Caloric restriction $(\mathrm{CR})$ is a reproducible and simple experimental manipulation that delays onset of numerous age-associated pathophysiological changes and prolongs the median and maximum lifespan in various laboratory models (e.g., yeast, worms, and mammals) $[19,20]$. A recent report showed that CR exerted beneficial effects on nonhuman primates, which suggested the effectiveness of CR in humans [21]. Therefore, $\mathrm{CR}$ mimetics, which mimic the underlying mechanisms of the beneficial effects of $\mathrm{CR}$, have attracted attention [22]. Previous studies have described that beneficial effects of $\mathrm{CR}$ including various physiological and molecular mechanisms [23]. These mechanisms include enhancement of mitochondrial biogenesis, suppression of inflammation, mitigation of oxidative stress, suppression of growth hormone/insulin-like growth factor (GH/IGF-1) signaling, mechanistic target of rapamycin complex 1 activity, and activation of sirtuin. Of note, several of these mechanisms are directly or indirectly relevant to mitochondria. In fact, we have shown that mitochondrial regulation in white adipose tissue (WAT) contributes to the beneficial effects of CR [24,25].

WAT largely comprises adipocytes, but also comprises adipose-derived stem cells (ADSC), fibroblasts, macrophages, and other immune cells [26]. Adipocytes store excess energy in the form of triglycerides (TG). Adipocytes are endocrine cells that secrete adipokines, such as adiponectin, leptin, and pro-inflammatory cytokines [26,27]. Adiponectin is a representative beneficial adipokine with the ability to improve insulin resistance by activating AMP-activated protein kinase (AMPK) in skeletal muscle and the liver [26,28]. Leptin participates in diverse physiological processes, including energy homeostasis, reproduction, angiogenesis, and the immune system [29]. Pro-inflammatory adipokines, such as interleukin-6, tumor necrosis factor $\alpha(\mathrm{TNF} \alpha)$, serpin family E member 1, and monocyte chemoattractant protein-1, cause inflammatory reactions and insulin resistance [30-33]. The secretory profile and characteristics of WAT vary depending on the size of adipocytes. Hypertrophic adipocytes with a large amount of TG, which are observed in obese individuals, preferentially secrete pro-inflammatory adipokines, thereby inducing local inflammation and insulin resistance $[34,35]$. In contrast, small adipocytes with a modest amount of TG, which are frequently observed in CR models, secrete more adiponectin and less monocyte chemoattractant protein- 1 and $\mathrm{TNF} \alpha$, leading to improved insulin sensitivity in the whole body [36]. The findings mentioned above suggest that obesity- or CR-associated differences in the characteristics of WAT greatly contribute to systemic metabolism.

As mentioned above, mitochondrial regulation is closely implicated in obesity-related pathology and the effects of CR, supporting the relationship between PGC-1 $\alpha$ and metabolic states in WAT. Despite many reviews of PGC- $1 \alpha$, few papers currently focus on and comprehensively highlight its link with metabolic states. Therefore, to provide novel insights into the physiological significance of PGC- $1 \alpha$, this review outlines the functions of mitochondria and the involvement of PGC- $1 \alpha$ with obesity- and CR-related physiological changes in WAT, which is a tissue involved in whole-body metabolism.

\section{Mitochondria and PGC-1 $\alpha$ in WAT during Obesity or CR}

\subsection{Overview of Mitochondrial Roles in WAT}

Adipocytes in WAT contain small and elongated mitochondria in the narrow cytoplasmic space, resulting from a large, unilocular lipid droplet formed by TG [37,38]. White adipocytes have been typically suspected to have a small number of mitochon- 
dria [37]. Some previous reports and reviews have described the relationship between mitochondria and white adipocyte-specific functions, such as adipocyte differentiation (or adipogenesis), lipid homeostasis, and insulin sensitivity $[39,40]$. Wilson-Fritch and colleagues showed that in 3T3-L1 cells (mouse fibroblasts with the ability to differentiate into adipocytes under specific conditions), mitochondrial capacity is activated depending on differentiation of adipocytes [41]. This finding could be explained by the requirement of a large amount of energy for the differentiation process of adipocytes [41]. During differentiation of adipocytes, transcriptional factors, including CCAAT/enhancer binding proteins, ERR $\alpha$, and PPAR $\gamma$, are sequentially induced, which in turn promote maturation of adipocytes [42-44]. Interestingly, PGC-1 $\alpha$ is also upregulated in fully differentiated 3T3-L1 adipocytes, indicating an association between adipogenesis and mitochondrial biogenesis [44]. This is supported by the finding that some mouse models with adipose tissue-specific deletion of mitochondria-related factors show lipoatrophy or lipodystrophy, which represent loss of WAT [45].

Mitochondria generally contribute to the regulation of lipid metabolism via $\beta$-oxidation as follows: Fatty acid (FA) is transported into mitochondria through carnitine palmitoyl transferases in the form of acyl-coenzyme A (acyl-CoA) [46]. In the mitochondrial matrix, acyl-CoAs are oxidized into acetyl-CoAs, which are eventually metabolized in the tricarboxylic acid (TCA) cycle [46]. Furthermore, mitochondria reportedly provide the key factors for de novo synthesis of both FA and TG, including citrate, glycerol 3-phosphate (G3P), and nicotinamide adenine dinucleotide phosphate (NADPH) [47,48]. In nutrient-rich conditions, citrate, which is an intermediate of the TCA cycle in mitochondria, is shuttled into the cytosol through the citrate carrier [49]. Citrate is then converted into oxaloacetate and acetyl-coenzyme A by ATP-citrate lyase [50]. Subsequently, acetyl-CoA is used for FA synthesis [50]. In fact, PGC- $1 \alpha$ reportedly induces lipogenesis by the production of citrate in tumors, thereby promoting tumor growth [51]. In addition, oxaloacetate in the cytosol is converted into phosphoenolpyruvate (PEP) by PEP carboxykinase (PEPCK), resulting in G3P formation [52,53]. G3P is dephosphorylated into glycerol, which is esterified with FA to form TG [52]. In addition to citrate and oxaloacetate, malate is an intermediate of the TCA cycle, which is important for lipogenesis. Malate is transported into the cytosol and converted into pyruvate by malic enzyme [54]. In this process, NADPH, a coenzyme for FA synthesis, is generated [55]. These findings underscore that mitochondria regulate both lipid metabolism and lipogenesis.

Insulin sensitivity is closely involved in lipogenesis via transcriptional regulation of FA synthesis-related factors in white adipocytes $[56,57]$. The following studies are examples indicating the association between mitochondria and insulin sensitivity. Wang and colleagues showed that inhibitors of mitochondrial respiratory complexes or knockdown of Tfam attenuate insulin signaling in WAT [58]. However, primary adipocytes established from subcutaneous WAT of obese patients have been shown to exhibit increased mitochondrial respiration despite their insulin resistance [59]. The authors described that this increase is a compensatory reaction for attenuated glucose metabolism due to insulin resistance [59]. Therefore, although it remains to be determined whether mitochondria are directly or indirectly associated with insulin sensitivity, mitochondria may participate in lipogenesis via the regulation of insulin signaling in addition to the supply of metabolic intermediates.

\subsection{Function and Regulation of PGC-1 $\alpha$ in Obese WAT}

Obesity impairs mitochondrial biogenesis and oxidative metabolism in WAT [41]. White adipocytes isolated from ob/ob mice or $\mathrm{db} / \mathrm{db}$ mice (genetic obesity models) show a comprehensive decrease in the expression of genes encoding mitochondrial proteins and a decline in oxygen consumption and citrate synthase activity $[42,60,61]$. In agreement with the results of experimental animal models, several studies have provided evidence that WAT in humans with obesity shows low levels of mtDNA and proteins comprising mitochondrial respiratory complexes $[41,62-64]$. A study showed that PGC- $1 \alpha$ was de- 
creased in WAT of obese rodents, and Nrf1 and Tfam mRNA expression, protein abundance of cytochrome c oxidase subunit IV, mtDNA levels, and mitochondrial density were also downregulated [65]. This study also identified TNF $\alpha$ as a cause of obesity-induced decrease in PGC- $1 \alpha$ expression and mitochondrial dysfunction [65]. Similarly, human studies have shown that obesity attenuates PGC- $1 \alpha$ expression in WAT $[63,64,66,67]$. Furthermore, Kleiner and colleagues found that adipose tissue-specific Pgc-1 $\alpha$ knockout (KO) mice fed a high-fat diet displayed decreased levels of genes involved in oxidative phosphorylation and $\beta$-oxidation, impaired glucose tolerance, and insulin resistance [68]. These findings suggest that downregulation of PGC- $1 \alpha$ in WAT is associated with obesity-related disturbance of whole-body metabolism, although PGC- $1 \alpha$ is endogenously expressed at low levels in WAT [2].

Adipocytes observed in obese WAT generally show an increased cell size (hypertrophy), rather than cell number (hyperplasia) [41]. As described above, hypertrophic adipocytes trigger insulin resistance. Conversely, hyperplasia of WAT represents the presence of many small adipocytes, which is associated with improvement of insulin sensitivity [69]. Hyperplasia is associated with the induction of adipocyte differentiation, namely adipogenesis [41]. Because of the relationship between adipogenesis and mitochondrial biogenesis, mitochondrial regulation by PGC- $1 \alpha$ is predicted to be involved in the pathology of obesity via morphological changes in white adipocytes. However, markers of white adipocyte differentiation remain unchanged in WAT of adipose tissue-specific Pgc-1 $\alpha$ $\mathrm{KO}$ mice [68]. Hypertrophy and hyperplasia are known to be regulated by a complicated paracrine mechanism between ADSCs and mature adipocytes [70]. Additionally, to the best of our knowledge, no study has shown direct participation of PGC- $1 \alpha$ in white adipocyte differentiation. PGC- $1 \alpha$ is widely accepted as a marker of transdifferentiation of white into brown adipocytes (known as "beiging") [71]. Therefore, mitochondrial biogenesis regulated by PGC- $1 \alpha$ may play an important, but not necessary, role in the differentiation of white adipocytes.

Negative regulators of PGC- $1 \alpha$, including receptor-interacting protein 140 (RIP140), p53, DNA methyltransferase 3 (DNMT3), and MYB binding protein (p160) 1a (MYBBP1a) and Parkin interacting substrate (PARIS), are considered to be responsible for obesityinduced downregulation of PGC-1 $\alpha$ [72]. Hence, we explain the relationship between each negative regulator and PGC- $1 \alpha$ in the following paragraphs.

RIP140 is a coregulator of a number of nuclear receptors and several other transcription factors in various tissues and organs [73,74]. RIP140 interacts with PGC- $1 \alpha$ and negatively regulates its transcriptional activity [74]. Leonardsson and colleagues showed that Rip140 expression was increased in relation to differentiation into adipocytes in 3T3-L1 cells [75]. Subsequently, Powelka and colleagues reported that RIP140 suppressed oxidative metabolism and mitochondrial biogenesis in adipocytes [76]. Moreover, RIP140 depletion has been shown to prevent obesity-induced glucose intolerance and insulin resistance in mice $[75,76]$. These findings indicate the substantial contribution of RIP140 to the pathology of obesity via downregulated PGC- $1 \alpha$ in WAT.

The tumor suppressor $\mathrm{p} 53$ is responsive to various stresses, and accumulated evidence has also strongly suggested that p53 greatly contributes to mitochondrial regulation [77,78]. Our laboratory has identified a suppressive effect of p53 on PGC- $1 \alpha$ expression levels and mtDNA content in 3T3-L1 adipocytes, but not in C2C12 myocytes [79]. Additionally, Maser and colleagues found that telomere dysfunction-induced p53 repressed PGC- $1 \alpha$ expression, which led to mitochondrial dysfunction [80]. Several p53-deficient mouse models have been reported to be resistant to obesity and show upregulated PGC- $1 \alpha$ expression. Fat-specific p53 KO mice show improved insulin sensitivity by preventing senescence-like features in WAT [81]. A research group described that PGC- $1 \alpha$ and mitochondrial genes were increased in subcutaneous WAT of systemic $p 53 \mathrm{KO}$ mice, which showed low WAT weight and improved glucose tolerance [82]. Similarly, in vivo transient repression of p53 by the CreERT2/loxP system or administration of pifithrin- $\alpha$ (inhibitor of p53 transcriptional activity) induce PGC- $1 \alpha$ expression in WAT, and reduce the respiratory exchange ratio [83]. 
DNMT3 plays a central role in epigenetic modifications of the genome via DNA methylation [84]. Barrès and colleagues showed that, in skeletal muscle from patients with T2DM, DNMT3-related non-CpG hypermethylation occurred in the PGC-1 $\alpha$ promoter, which resulted in decreased PGC-1 $\alpha$ gene expression and mtDNA levels [85]. Furthermore, DNMTs are increased in WAT in patients with obesity, thereby inducing the methylation rate of the promoter region of the Krüppel-like factor 4 (KLF4) gene (an anti-inflammatory factor) and suppressing this expression [86]. These studies suggest that DNMT3 is associated with obesity-related downregulation of PGC-1 $\alpha$ expression and mitochondrial function in adipocytes or WAT, despite no direct evidence. MYBBP1a represses transcriptional activity of PGC- $1 \alpha$ by direct interaction in skeletal muscle [87]. PARIS, which is a transcriptional factor known as zinc-finger protein 746, attenuates $P G C-1 \alpha$ expression by binding to insulin responsive sequences in the PGC-1 $\alpha$ promoter region [88]. Whether MYBBP1a and PARIS are expressed in adipocytes or WAT remains to be evaluated. However, these reports raise the possibility of the contribution of MYBBP1a or PARIS to a decrease in PGC-1 $\alpha$ in obese WAT.

\subsection{Function and Regulation of PGC- $1 \alpha$ in WAT during $C R$}

Studies that have analyzed involvement of CR with mitochondria or PGC-1 $\alpha$ in WAT are currently limited. In fact, many studies have addressed the effects of $C R$ on mitochondrial biogenesis and efficiency in skeletal muscle, brain, or BAT in rodent models [89]. However, our proteome analysis showed that $\mathrm{CR}$ enhanced mitochondrial biogenesis in WAT, but not in BAT [90]. In agreement with our result, a microarray study performed by Linford and colleagues showed CR-induced upregulation of genes involved in mitochondrial oxidative phosphorylation in WAT [91]. Nisoli and colleagues reported that CR increased Pgc-1 $\alpha$ and mtDNA levels in WAT [92]. Similarly, Pardo and colleagues showed that CR-induced upregulation of mitochondrial genes in WAT depended on PGC- $1 \alpha$ and PGC-1 $\beta$ using double-KO mice [93]. Another study also showed that CR was more likely to upregulate mRNA levels of thermogenic genes and $P g c-1 \alpha$ in WAT than in BAT, which represented induction of beiging [94]. These studies suggest the importance of mitochondrial regulation and PGC- $1 \alpha$ in WAT for the effects of CR.

The suppression of negative regulators of PGC-1 $\alpha$ is likely to be a mechanism involved in CR-upregulated PGC- $1 \alpha$ expression. For example, CR reduced TNF $\alpha$ gene expression levels in WAT [95]. Likewise, transcriptome analysis of WAT from CR mice showed p53 gene expression was suppressed by CR [96]. Additionally, Wang and colleagues demonstrated that aging induced RIP140 expression, while CR prevented this induction in WAT [97]. The authors also revealed that Rip140 KO female mice exhibit an extended lifespan [97]. These studies support the proposal that the suppression of negative regulators can contribute to CR-upregulated PGC- $1 \alpha$ expression and mitochondrial biogenesis in WAT.

Among the positive regulators of PGC- $1 \alpha$, SIRT1 and AMPK are representative CRrelated mediators $[98,99]$. AMPK is activated in response to an energy expenditure-induced increase in the AMP/ATP ratio, thereby assisting in catabolic processes to supply energy [100]. AMPK enhances the transcriptional activity of PGC- $1 \alpha$ by promoting its phosphorylation, and also upregulates $P g c-1 \alpha$, resulting in activation of mitochondrial metabolism and biogenesis [101,102]. SIRT1 is an NAD-dependent deacetylase that greatly contributes to the beneficial effects of CR $[103,104]$. SIRT1 is involved in mitochondrial biogenesis by stimulating activity of PGC- $1 \alpha$ via its deacetylation, despite the controversy over whether this involvement is critical for regulation of PGC-1 $\alpha$ [105-108]. SIRT1-induced deacetylation of PGC- $1 \alpha$ is also regulated by AMPK [109]. The AMPK/SIRT1/PGC- $1 \alpha$ axis plays a central role in CR-related regulation of mitochondrial biogenesis in various organs and tissues, and is accepted as a main target of CR mimetics [22]. Resveratrol, which is a natural polyphenol with the ability to activate SIRT1, exerts beneficial effects on metabolic disorders as shown by some clinical trials [110]. Notably, resveratrol fails to increase mitochondrial gene levels in skeletal muscle of muscle-specific Pgc-1 $\alpha$ KO mice, but 
there are systemic effects of this compound on energy expenditure [111]. Resveratrol also upregulates $P g c-1 \alpha$ expression and lipid metabolism-related genes in WAT [111]. Moreover, several reviews have described that natural polyphenols induce beiging of WAT [112-114]. Taken together, these studies suggest that activation of the AMPK/SIRT1/PGC- $1 \alpha$ axis in WAT is likely to be involved in the systemic metabolic effects of CR.

In addition to the AMPK/SIRT1/PGC- $1 \alpha$ axis, we have recently identified sterol regulatory element-binding protein 1c (SREBP1c) and fibroblast growth factor 21 (FGF21) as WAT-specific mediators of CR-induced mitochondrial biogenesis [25,115]. Suppression of GH/IGF-1 signaling is a well-known and major mechanism of the beneficial effects of CR [116]. Although animal models with suppressed GH/IGF-1 signaling generally live longer, interestingly, $\mathrm{CR}$ can further extend longevity in these animals [117,118]. This finding indicates that GH/IGF-1 signaling-independent mechanisms are involved in the effects of CR [117,118]. Our microarray analysis of WAT in ad libitum-fed rats, CR rats, and dwarf rats with suppressed GH/IGF-1 signaling showed that CR induced expression of genes involved in FA synthesis and SREBP1c [119]. SREBP1c is a master transcriptional factor of these genes. To evaluate the contribution of SREBP1c to the effects of CR, we examined the phenotypes of Srebp-1c KO mice. In CR conditions, Srebp-1c KO mice showed loss of upregulation of genes involved in FA synthesis in WAT and suppression of extension of the lifespan [24]. In this study, we discovered that CR-induced upregulation of $P g c-1 \alpha$ and mtDNA levels were suppressed in WAT of Srebp-1c KO mice. Consistently, Srebp-1c KO mouse embryonic fibroblasts show decreased $P g c-1 \alpha$ and mtDNA levels, suggesting SREBP-1c-dependent regulation of $P g c-1 \alpha$ [24]. Furthermore, we found that SREBP-1c directly bound to the $P g c-1 \alpha$ promoter region, thereby activating its gene expression [24]. Our recent study also showed increased levels of PGC-1 $\alpha$ in Srebp-1c-overexpressing 3T3L1 adipocytes [120]. These findings suggest that SREBP-1c is a direct inducer of PGC-1 $\alpha$ expression and mitochondrial biogenesis.

FGF21 is a member of the endocrine FGF superfamily of which expression is highest in the liver [121]. However, $F g f 21$ is expressed in other tissues or organs, such as WAT, BAT, and skeletal muscle [122]. Circulating FGF21, which is mostly secreted from the liver, binds to FGF receptor (FGFR) and the beta-klotho (KLB) receptor complex in target tissues, which in turn regulates glucose and lipid metabolism [123]. Notably, FGF21 signaling induces $P g c-1 \alpha$ expression in adipocytes [124]. We recently reported that CR upregulated Fof 21 and Klb expression, as well as glucose transporter 1 and $P g c-1 \alpha$ expression, which are downstream genes of FGF21 signaling, in rat WATs [115]. These genes were also increased in $F g f 21$-overexpressing adipocytes [115]. Subsequently, we showed a decrease in $P g c-1 \alpha$ levels in $F g f 21 \mathrm{KO}$ mouse embryonic fibroblasts [120]. These results suggest that FGF21 contributes to CR-induced upregulation of $P g c-1 \alpha$ in WAT probably via an autocrine mechanism. Additionally, we found that $F g f 21$ levels were upregulated in Srebp1c-overexpressing adipocytes and downregulated in WAT of Srebp-1c KO mice [120]. This observation is consistent with a study of Véniant and colleagues who found that fat-specific SREBP-1c transgenic mice showed an increase of $F g f 21$ in WAT [125]. Therefore, SREBP-1c likely increases PGC-1 $\alpha$ expression not only directly, but indirectly, via FGF21.

\section{Discussion}

Accumulated evidence has shown functional changes of mitochondria in WAT in relation to the systemic metabolic state, including obesity and CR. The cause-and-effect relationship between PGC- $1 \alpha$ and the influence of obesity or CR on WAT is complicated. We aimed to provide insight into the physiological significance of alterations in PGC- $1 \alpha$ in WAT as follows.

Obesity is regarded as an over-nutrition-induced state. In the early phase of obesity, adipogenesis and lipid anabolism need to be extremely induced to metabolize excess nutrition, probably resulting in over-activation of mitochondria in WAT. The persistence of such a condition in mitochondria is generally considered to trigger production of more reactive oxygen species (ROS), which are byproducts of oxidative phosphorylation. In 
fact, several studies have shown that obesity upregulates mitochondrial ROS levels in WAT $[126,127]$. At low levels, ROS play an important role in insulin signal transduction and differentiation of adipocytes $[128,129]$. In contrast, higher ROS levels cause oxidative stress, mitochondrial dysfunction, and inflammation [130]. Therefore, mitochondria are damaged by being exposed to accumulated ROS depending on the progress of obese conditions. ROS also induce mutations in mtDNA [131]. Although PGC-1 $\alpha$ is involved in not only mitochondrial biogenesis, but improvement of oxidative stress, obesity-induced downregulation of PGC- $1 \alpha$ may represent a defensive reaction to accumulation of abnormal mtDNA that is likely to further exacerbate mitochondrial function.

$\mathrm{CR}$ is regarded as a chronic and mild energy shortage condition. CR significantly enhances lipid catabolism in the whole body, which allows more efficient systemic metabolism to compensate for an energy shortage [132]. A previous study and our study suggest that WAT contributes to this metabolic shift by promoting de novo synthesis of lipids, which are a more efficient source of energy than carbohydrates [25,132]. Considering that mitochondria play an important role in lipogenesis as mentioned above, CR-induced PGC- $1 \alpha$ in WAT may represent enhanced de novo lipogenesis, rather than lipid catabolism by $\beta$ oxidation. This notion is supported by the fact that SREBP-1c, which is a master regulator of FA synthesis, positively regulates Pgc-1 $\alpha$ expression in WAT [24,25].

At present, the above-mentioned topics remain to be fully clarified. In this manuscript, we review findings mainly based on studies that focus on the physiological changes from normal conditions to obese or CR conditions. However, there are many studies that demonstrate CR-related changes in obese conditions [133-137]. Investigation of the effects of CR on obesity physiology is important for evaluating the clinical significance of CR. Thus, further accumulation of relevant findings will aid in addressing the cause-and-effect relationship between PGC- $1 \alpha$ and obesity or CR.

Methodological limitations of the current research mentioned in this review include phenotypic differences between systemic and conditional $\mathrm{KO}$ mice. It is conceivable that metabolic alterations are especially susceptible to these differences. For instance, fat-specific conditional $\mathrm{KO}$ mice may provide experimental models suitable for more accurate analysis of targeted genes. Currently, the general fat-specific KO mice are not WAT-specific deficient models, because adiponectin-Cre, the transgene usually used to generate fat-specific $\mathrm{KO}$ models, works in both WAT and BAT [138]. Hence, the development of a technical method that allows conditional gene deletion to specifically target WAT is desired.

Regulation of mitochondrial dynamics is attributed to not only mitochondrial biogenesis, which is enhanced by PGC- $1 \alpha$, but also mitochondrial degradation by autophagic clearance, namely "mitophagy" [139]. Mitophagy is implicated in alterations in characteristics of adipocytes, especially beiging [139]. Therefore, a balance of mitochondrial biogenesis and mitophagy is probably important for maintenance of mitochondrial function in WAT, and regulation of PGC- $1 \alpha$ may be involved in this balance.

In conclusion, much of the evidence introduced in this review strongly indicates that PGC- $1 \alpha$ is a major player in regulating mitochondrial biogenesis or function in WAT in response to a systemic metabolic state (Figure 1). Further investigation of WAT- or white adipocyte-specific function of PGC- $1 \alpha$ will lead to identification of the novel mechanisms underlying the relationship between mitochondria and obesity- or CR-related physiological changes. 


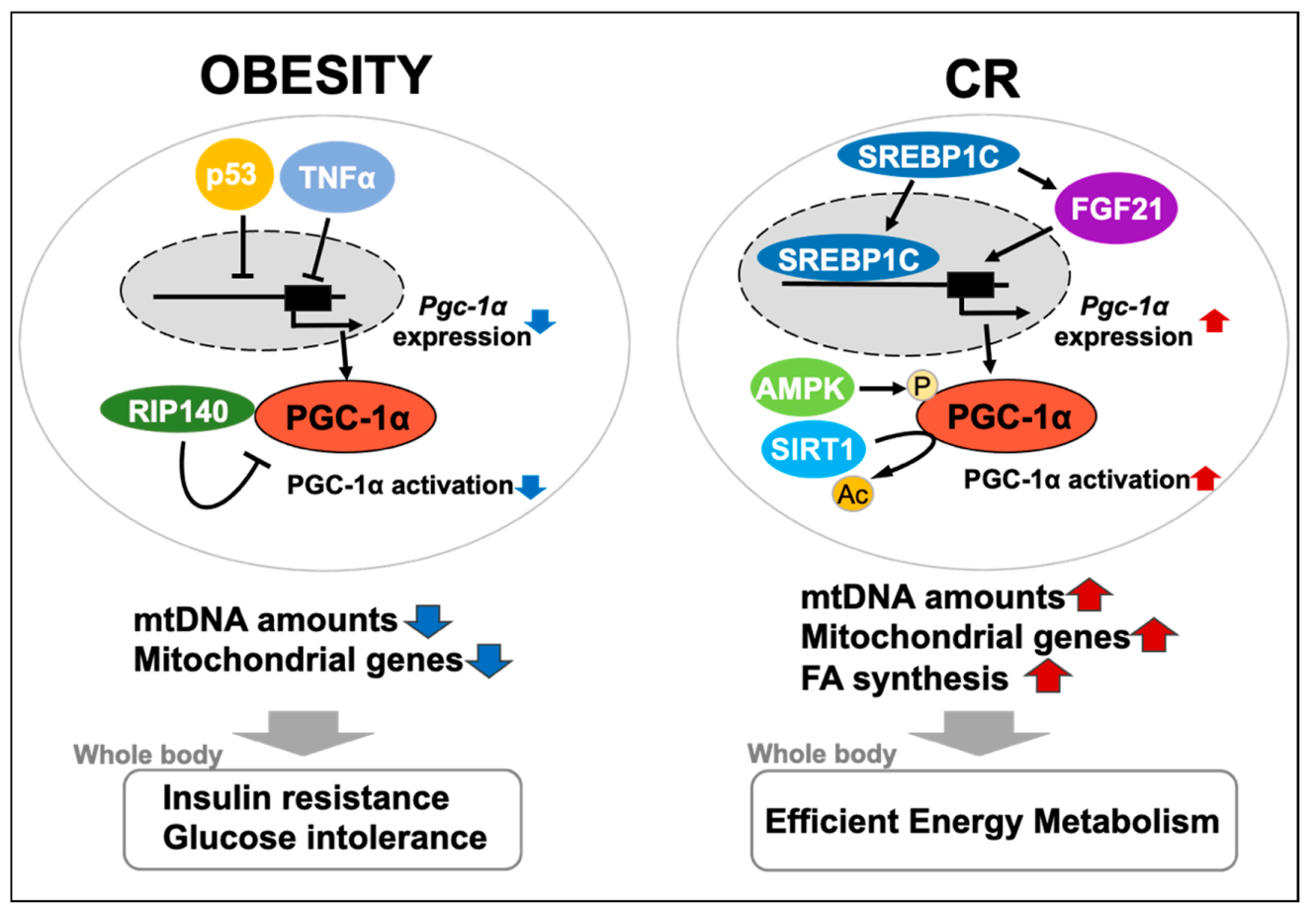

Figure 1. Regulation of PGC- $1 \alpha$ in white adipose tissue (WAT) and its impact on whole-body metabolism. In obese WAT, peroxisome proliferator-activated receptor $\gamma$ coactivator- $1 \alpha$ (PGC-1 $\alpha$ ) is transcriptionally silenced by p53 and tumor necrosis factor $\alpha(\mathrm{TNF} \alpha)$, and suppressed at the activity level by interacting with receptor-interacting protein 140 (RIP140). This triggers a decrease in the amount of mtDNA and expression of mitochondrial genes in WAT, resulting in obesity-related pathology (e.g., insulin resistance and glucose intolerance). In WAT, during caloric restriction (CR), PGC- $1 \alpha$ is transcriptionally upregulated by sterol regulatory element-binding protein 1c (SREBP-1c) and via the SREBP-1c-fibroblast growth factor 21 (FGF21) axis, and post-translationally activated by AMP-activated protein kinase (AMPK) and Sirtuin 1 (SIRT1). This induces fatty acid (FA) synthesis, in addition to increasing mtDNA and mitochondrial gene expression in WAT, resulting in efficient energy metabolism in the whole body.

Author Contributions: Conceptualization, M.K. and Y.H.; Writing—original draft preparation, M.K.; Writing-review and editing, Y.D., Y.N. and Y.H.; Visualization, Y.D. and Y.N.; Supervision, Y.H.; Project administration, M.K. and Y.H.; Funding acquisition, M.K. and Y.H. All authors have read and agreed to the published version of the manuscript.

Funding: This work was supported by a Grant-in-Aid for Young Scientists (No. 20K19686) (to M.K.), a Grant-in-Aid for Scientific Research (B) (No. 20H04130) (to Y.H.) from the Japan Society for the Promotion of Science.

Institutional Review Board Statement: Not applicable.

Informed Consent Statement: Not applicable.

Data Availability Statement: Not applicable.

Acknowledgments: We thank Ellen Knapp, and Charles Allan, from Edanz Group (https://enauthor-services.edanz.com/ac (accessed on 24 May 2021)) for editing a draft of this manuscript.

Conflicts of Interest: The authors declare no conflict of interest. 


\section{References}

1. Puigserver, P.; Spiegelman, B.M. Peroxisome proliferator-activated receptor-gamma coactivator 1 alpha (PGC-1 alpha): Transcriptional coactivator and metabolic regulator. Endocr. Rev. 2003, 24, 78-90. [CrossRef]

2. Puigserver, P.; Wu, Z.; Park, C.W.; Graves, R.; Wright, M.; Spiegelman, B.M. A cold-inducible coactivator of nuclear receptors linked to adaptive thermogenesis. Cell 1998, 92, 829-839. [CrossRef]

3. Wu, Z.; Puigserver, P.; Andersson, U.; Zhang, C.; Adelmant, G.; Mootha, V.; Troy, A.; Cinti, S.; Lowell, B.B.; Scarpulla, R.C.; et al. Mechanisms controlling mitochondrial biogenesis and respiration through the thermogenic coactivator PGC-1. Cell 1999, 98, 115-124. [CrossRef]

4. Evans, M.J.; Scarpulla, R.C. NRF-1: A trans-activator of nuclearencoded respiratory genes in animal cells. Genes Dev. 1990, 4, 1023-1034. [CrossRef]

5. Scarpulla, R.C. Nuclear control of respiratory gene expression in mammalian cells. J. Cell Biochem. 2006, 97, 673-683. [CrossRef] [PubMed]

6. Scarpulla, R.C.; Vega, R.B.; Kelly, D.P. Transcriptional integration of mitochondrial biogenesis. Trends Endocrinol. Metab. 2012, 23, 459-466. [CrossRef]

7. Huss, J.M.; Kopp, R.P.; Kelly, D.P. PGC-1 $\alpha$ coactivates the cardiac-enriched nuclear receptors estrogen-related receptor- $\alpha$ and $-\gamma$. J. Biol. Chem. 2002, 277, 40265-40274. [CrossRef]

8. Mootha, V.K.; Handschin, C.; Arlow, D.; Xie, X.; St Pierre, J.; Sihag, S.; Yang, W.; Altshuler, D.; Puigserver, P.; Patterson, N.; et al. Erralpha and Gabpa/b specify PGC-1alpha-dependent oxidative phosphorylation gene expression that is altered in diabetic muscle. Proc. Natl. Acad. Sci. USA 2004, 101, 6570-6575. [CrossRef] [PubMed]

9. Virbasius, J.V.; Virbasius, C.A.; Scarpulla, R.C. Identity of GABP with NRF-2, a multisubunit activator of cytochrome oxidase expression, reveals a cellular role for an ETS domain activator of viral promoters. Genes Dev. 1993, 7, 380-392. [CrossRef]

10. Ngo, H.B.; Lovely, G.A.; Phillips, R.; Chan, D.C. Distinct structural features of TFAM drive mitochondrial DNA packaging versus transcriptional activation. Nat. Commun. 2014, 5, 3077. [CrossRef]

11. Hirschey, M.D.; Shimazu, T.; Goetzman, E.; Jing, E.; Schwer, B.; Lombard, D.B.; Grueter, C.A.; Harris, C.; Biddinger, S.; Ilkayeva, O.R.; et al. SIRT3 regulates mitochondrial fatty-acid oxidation by reversible enzyme deacetylation. Nature 2010, 464, 121-125. [CrossRef]

12. Qiu, X.; Brown, K.; Hirschey, M.D.; Verdin, E.; Chen, D. Calorie restriction reduces oxidative stress by SIRT3-mediated SOD2 activation. Cell Metab. 2010, 12, 662-667. [CrossRef] [PubMed]

13. Kong, X.; Wang, R.; Xue, Y.; Liu, X.; Zhang, H.; Chen, Y.; Fang, F.; Chang, Y. Sirtuin 3, a new target of PGC-1alpha, plays an important role in the suppression of ROS and mitochondrial biogenesis. PLoS ONE 2010, 5, e11707. [CrossRef]

14. Van Gaal, L.F.; Mertens, I.L.; de Block, C.E. Mechanisms linking obesity with cardiovascular disease. Nature 2006, 444, 875-880. [CrossRef]

15. Schwartz, M.W.; Seeley, R.J.; Zeltser, L.M.; Drewnowski, A.; Ravussin, E.; Redman, L.M.; Leibel, R.L. Obesity Pathogenesis: An Endocrine Society Scientific Statement. Endocr. Rev. 2017, 38, 267-296. [CrossRef]

16. Rutkowski, J.M.; Stern, J.H.; Scherer, P.E. The cell biology of fat expansion. J. Cell. Biol. 2015, 208, 501-512. [CrossRef]

17. Heymsfield, S.B.; Wadden, T.A. Mechanisms, Pathophysiology, and Management of Obesity. N. Engl. J. Med. 2017, 376, 254-266. [CrossRef] [PubMed]

18. Prasun, P. Mitochondrial dysfunction in metabolic syndrome. Biochim. Biophys. Acta Mol. Basis Dis. 2020, 1866, 165838. [CrossRef] [PubMed]

19. Yu, B.P. Modulation of Aging Processes by Dietary Restriction; CRC Press: Boca Raton, FL, USA, 1994.

20. Ingram, D.K.; de Cabo, R. Calorie restriction in rodents: Caveats to consider. Aging Res. Rev. 2017, 39, 15-28. [CrossRef]

21. Mattison, J.A.; Colman, R.J.; Beasley, T.M.; Allison, D.B.; Kemnitz, J.W.; Roth, G.S.; Ingram, D.K.; Weindruch, R.; de Cabo, R.; Anderson, R.M. Caloric restriction improves health and survival of rhesus monkeys. Nat. Commun. 2017, 8, 14063. [CrossRef]

22. Madeo, F.; Carmona-Gutierrez, D.; Hofer, S.J.; Kroemer, G. Caloric Restriction Mimetics against Age-Associated Disease: Target, Mechanisms, and Therapeutic Potential. Cell Metab. 2019, 29, 592-610. [CrossRef]

23. Hoshino, S.; Kobayashi, M.; Higami, Y. Mechanisms of the anti-aging and prolongevity effects of caloric restriction: Evidence from studies of genetically modified animals. Aging 2018, 10, 2243-2251. [CrossRef] [PubMed]

24. Fujii, N.; Narita, T.; Okita, N.; Kobayashi, M.; Furuta, Y.; Chujo, Y.; Sakai, M.; Yamada, A.; Takeda, K.; Konishi, T.; et al. Sterol regulatory element-binding protein-1c orchestrates metabolic remodeling of white adipose tissue by caloric restriction. Aging Cell 2017, 16, 508-517. [CrossRef] [PubMed]

25. Kobayashi, M.; Fujii, N.; Narita, T.; Higami, Y. SREBP-1c-Dependent Metabolic Remodeling of White Adipose Tissue by Caloric Restriction. Int. J. Mol. Sci. 2018, 19, 3335. [CrossRef]

26. Ouchi, N.; Parker, J.L.; Lugus, J.J.; Walsh, K. Adipokines in inflammation and metabolic disease. Nat. Rev. Immunol. 2011, 11, 85-97. [CrossRef] [PubMed]

27. Cinti, S. The adipose organ. Prostaglandins Leukot. Essent. Fatty Acids 2005, 73, 9-15. [CrossRef] [PubMed]

28. Yamauchi, T.; Kamon, J.; Waki, H.; Terauchi, Y.; Kubota, N.; Hara, K.; Mori, Y.; Ide, T.; Murakami, K.; Tsuboyama-Kasaoka, N.; et al. The fat-derived hormone adiponectin reverses insulin resistance associated with both lipoatrophy and obesity. Nat. Med. 2001, 7, 941-946. [CrossRef] [PubMed]

29. Martínez-Sánchez, N. There and Back Again: Leptin Actions in White Adipose Tissue. Int. J. Mol. Sci. 2020, 21, 6039. [CrossRef] 
30. Hotamisligil, G.S.; Arner, P.; Caro, J.F.; Atkinson, R.L.; Spiegelman, B.M. Increased adipose tissue expression of tumor necrosis factor-alpha in human obesity and insulin resistance. J. Clin. Investig. 1995, 95, 2409-2415. [CrossRef]

31. Sindhu, S.; Thomas, R.; Shihab, P.; Sriraman, D.; Behbehani, K.; Ahmad, R. Obesity Is a Positive Modulator of IL-6R and IL-6 Expression in the Subcutaneous Adipose Tissue: Significance for Metabolic Inflammation. PLoS ONE 2015, 10, e0133494. [CrossRef] [PubMed]

32. Kanda, H.; Tateya, S.; Tamori, Y.; Kotani, K.; Hiasa, K.; Kitazawa, R.; Kitazawa, S.; Miyachi, H.; Maeda, S.; Egashira, K.; et al. MCP-1 contributes to macrophage infiltration into adipose tissue, insulin resistance, and hepatic steatosis in obesity. J. Clin. Investig. 2006, 116, 1494-1505. [CrossRef] [PubMed]

33. Wang, B.; Jenkins, J.R.; Trayhurn, P. Expression and secretion of inflammation-related adipokines by human adipocytes differentiated in culture: Integrated response to TNF-alpha. Am. J. Physiol. Endocrinol. Metab. 2005, 288, E731-E740. [CrossRef] [PubMed]

34. Gnacińska, M.; Małgorzewicz, S.; Stojek, M.; Łysiak-Szydłowska, W.; Sworczak, K. Role of adipokines in complications related to obesity: A review. Adv. Med. Sci. 2009, 54, 150-157. [CrossRef] [PubMed]

35. Torres-Leal, F.L.; Fonseca-Alaniz, M.H.; Rogero, M.M.; Tirapegui, J. The role of inflamed adipose tissue in the insulin resistance. Cell Biochem. Funct. 2010, 28, 623-631. [CrossRef]

36. Van Baak, M.A.; Mariman, E.C.M. Mechanisms of weight regain after weight loss-The role of adipose tissue. Nat. Rev. Endocrinol. 2019, 15, 274-287. [CrossRef]

37. Kopecký, J.; Rossmeisl, M.; Flachs, P.; Bardová, K.; Brauner, P. Mitochondrial uncoupling and lipid metabolism in adipocytes. Biochem. Soc. Trans. 2001, 29, 791-797. [CrossRef]

38. Villarroya, J.; Giralt, M.; Villarroya, F. Mitochondrial DNA: An up-and-coming actor in white adipose tissue pathophysiology. Obesity 2009, 17, 1814-1820. [CrossRef]

39. De Pauw, A.; Tejerina, S.; Raes, M.; Keijer, J.; Arnould, T. Mitochondrial (dys)function in adipocyte (de)differentiation and systemic metabolic alterations. Am. J. Pathol. 2009, 175, 927-939. [CrossRef]

40. Heinonen, S.; Jokinen, R.; Rissanen, A.; Pietiläinen, K.H. White adipose tissue mitochondrial metabolism in health and in obesity. Obes. Rev. 2020, 21, e12958. [CrossRef]

41. Wilson-Fritch, L.; Burkart, A.; Bell, G.; Mendelson, K.; Leszyk, J.; Nicoloro, S.; Czech, M.; Corvera, S. Mitochondrial biogenesis and remodeling during adipogenesis and in response to the insulin sensitizer rosiglitazone. Mol. Cell. Biol. 2003, 23, 1085-1094. [CrossRef]

42. Lefterova, M.I.; Lazar, M.A. New developments in adipogenesis. Trends Endocrinol. Metab. 2009, 20, 107-114. [CrossRef] [PubMed]

43. Rosen, E.D.; MacDougald, O.A. Adipocyte differentiation from the inside out. Nat. Rev. Mol. Cell. Biol. 2006, 7, 885-896. [CrossRef]

44. Ijichi, N.; Ikeda, K.; Horie-Inoue, K.; Yagi, K.; Okazaki, Y.; Inoue, S. Estrogen-related receptor alpha modulates the expression of adipogenesis-related genes during adipocyte differentiation. Biochem. Biophys. Res. Commun. 2007, 358, 813-818. [CrossRef]

45. Kobayashi, M.; Nezu, Y.; Tagawa, R.; Higami, Y. Mitochondrial Unfolded Protein Responses in White Adipose Tissue: Lipoatrophy, Whole-Body Metabolism and Lifespan. Int. J. Mol. Sci. 2021, 22, 2854. [CrossRef]

46. Steensels, S.; Ersoy, B.A. Fatty acid activation in thermogenic adipose tissue. Biochim. Biophys. Acta Mol. Cell. Biol. Lipids 2019, 1864, 79-90. [CrossRef] [PubMed]

47. Benador, I.Y.; Veliova, M.; Mahdaviani, K.; Petcherski, A.; Wikstrom, J.D.; Assali, E.A.; Acín-Pérez, R.; Shum, M.; Oliveira, M.F.; Cinti, S.; et al. Mitochondria Bound to Lipid Droplets Have Unique Bioenergetics, Composition, and Dynamics that Support Lipid Droplet Expansion. Cell Metab. 2018, 27, 869-885. [CrossRef] [PubMed]

48. Jitrapakdee, S.; Vidal-Puig, A.; Wallace, J.C. Anaplerotic roles of pyruvate carboxylase in mammalian tissues. Cell. Mol. Life Sci. 2006, 63, 843-854. [CrossRef] [PubMed]

49. Klingenberg, M. Kinetic study of the tricarboxylate carrier in rat liver mitochondria. Eur. J. Biochem. 1972, 26, 587-594. [CrossRef] [PubMed]

50. Hsiao, W.Y.; Guertin, D.A. De Novo Lipogenesis as a Source of Second Messengers in Adipocytes. Curr. Diabetes Rep. 2019, 19, 138. [CrossRef] [PubMed]

51. Bhalla, K.; Hwang, B.J.; Dewi, R.E.; Ou, L.; Twaddel, W.; Fang, H.B.; Vafai, S.B.; Vazquez, F.; Puigserver, P.; Boros, L.; et al. PGC1 $\alpha$ promotes tumor growth by inducing gene expression programs supporting lipogenesis. Cancer Res. 2011, 71, $6888-6898$. [CrossRef]

52. Reshef, L.; Olswang, Y.; Cassuto, H.; Blum, B.; Croniger, C.M.; Kalhan, S.C.; Tilghman, S.M.; Hanson, R.W. Glyceroneogenesis and the triglyceride/fatty acid cycle. J. Biol. Chem. 2003, 278, 30413-30416. [CrossRef] [PubMed]

53. Olswang, Y.; Cohen, H.; Papo, O.; Cassuto, H.; Croniger, C.M.; Hakimi, P.; Tilghman, S.M.; Hanson, R.W.; Reshef, L. A mutation in the peroxisome proliferator-activated receptor gamma-binding site in the gene for the cytosolic form of phosphoenolpyruvate carboxykinase reduces adipose tissue size and fat content in mice. Proc. Natl. Acad. Sci. USA 2002, 99, 625-630. [CrossRef]

54. Liu, L.; Shah, S.; Fan, J.; Park, J.O.; Wellen, K.E.; Rabinowitz, J.D. Malic enzyme tracers reveal hypoxia-induced switch in adipocyte NADPH pathway usage. Nat. Chem. Biol. 2016, 12, 345-352. [CrossRef]

55. Kather, H.; Brand, K. Origin of hydrogen required for fatty acid synthesis in isolated rat adipocytes. Arch. Biochem. Biophys. 1975, 170,417-426. [CrossRef] 
56. Wong, R.H.; Sul, H.S. Insulin signaling in fatty acid and fat synthesis: A transcriptional perspective. Curr. Opin. Pharmacol. 2010, 10, 684-691. [CrossRef] [PubMed]

57. Krycer, J.R.; Quek, L.E.; Francis, D.; Zadoorian, A.; Weiss, F.C.; Cookem, K.C.; Nelson, M.E.; Diaz-Vegas, A.; Humphrey, S.J.; Scalzo, R.; et al. Insulin signaling requires glucose to promote lipid anabolism in adipocytes. J. Biol. Chem. 2020, 295, 13250-13266. [CrossRef]

58. Wang, C.H.; Wang, C.C.; Huang, H.C.; Wei, Y.H. Mitochondrial dysfunction leads to impairment of insulin sensitivity and adiponectin secretion in adipocytes. FEBS J. 2013, 280, 1039-1050. [CrossRef]

59. Böhm, A.; Keuper, M.; Meile, T.; Zdichavsky, M.; Fritsche, A.; Häring, H.U.; de Angelis, M.H.; Staiger, H.; Franko, A. Increased mitochondrial respiration of adipocytes from metabolically unhealthy obese compared to healthy obese individuals. Sci. Rep. 2020, 10, 12407. [CrossRef] [PubMed]

60. Rong, J.X.; Qiu, Y.; Hansen, M.K.; Zhu, L.; Zhang, V.; Xie, M.; Okamoto, Y.; Mattie, M.D.; Higashiyama, H.; Asano, S.; et al. Adipose mitochondrial biogenesis is suppressed in $\mathrm{db} / \mathrm{db}$ and high-fat diet-fed mice and improved by rosiglitazone. Diabetes 2007, 56, 1751-1760. [CrossRef]

61. Choo, H.J.; Kim, J.H.; Kwon, O.B.; Lee, C.S.; Mun, J.Y.; Han, S.S.; Yoon, Y.S.; Yoon, G.; Choi, K.M.; Ko, Y.G. Mitochondria are impaired in the adipocytes of type 2 diabetic mice. Diabetologia 2006, 49, 784-791. [CrossRef] [PubMed]

62. Pietiläinen, K.H.; Naukkarinen, J.; Rissanen, A.; Saharinen, J.; Ellonen, P.; Keränen, H.; Suomalainen, A.; Götz, A.; Suortti, T.; Yki-Järvinen, H.; et al. Global transcript profiles of fat in monozygotic twins discordant for BMI: Pathways behind acquired obesity. PLoS Med. 2008, 5, e51. [CrossRef]

63. Heinonen, S.; Buzkova, J.; Muniandy, M.; Kaksonen, R.; Ollikainen, M.; Ismail, K.; Hakkarainen, A.; Lundbom, J.; Lundbom, N.; Vuolteenaho, K.; et al. Impaired Mitochondrial Biogenesis in Adipose Tissue in Acquired Obesity. Diabetes 2015, 64, 3135-3145. [CrossRef] [PubMed]

64. Heinonen, S.; Muniandy, M.; Buzkova, J.; Mardinoglu, A.; Rodríguez, A.; Frühbeck, G.; Hakkarainen, A.; Lundbom, J.; Lundbom, N.; Kaprio, J.; et al. Mitochondria-related transcriptional signature is downregulated in adipocytes in obesity: A study of young healthy MZ twins. Diabetologia 2017, 60, 169-181. [CrossRef]

65. Valerio, A.; Cardile, A.; Cozzi, V.; Bracale, R.; Tedesco, L.; Pisconti, A.; Palomba, L.; Cantoni, O.; Clementi, E.; Moncada, S.; et al. TNF-alpha downregulates eNOS expression and mitochondrial biogenesis in fat and muscle of obese rodents. J. Clin. Investig. 2006, 116, 2791-2798. [CrossRef] [PubMed]

66. Semple, R.K.; Crowley, V.C.; Sewter, C.P.; Laudes, M.; Christodoulides, C.; Considine, R.V.; Vidal-Puig, A.; O’Rahilly, S. Expression of the thermogenic nuclear hormone receptor coactivator PGC-1alpha is reduced in the adipose tissue of morbidly obese subjects. Int. J. Obes. Relat. Metab. Disord. 2004, 28, 176-179. [CrossRef] [PubMed]

67. Hammarstedt, A.; Jansson, P.A.; Wesslau, C.; Yang, X.; Smith, U. Reduced expression of PGC-1 and insulin-signaling molecules in adipose tissue is associated with insulin resistance. Biochem. Biophys. Res. Commun. 2003, 301, 578-582. [CrossRef]

68. Kleiner, S.; Mepani, R.J.; Laznik, D.; Ye, L.; Jurczak, M.J.; Jornayvaz, F.R.; Estall, J.L.; Chatterjee, B.D.; Shulman, G.I.; Spiegelman, B.M. Development of insulin resistance in mice lacking PGC-1 $\alpha$ in adipose tissues. Proc. Natl. Acad. Sci. USA 2012, 109, 9635-9640. [CrossRef]

69. Hoffstedt, J.; Arner, E.; Wahrenberg, H.; Andersson, D.P.; Qvisth, V.; Löfgren, P.; Rydén, M.; Thörne, A.; Wirén, M.; Palmér, M.; et al. Regional impact of adipose tissue morphology on the metabolic profile in morbid obesity. Diabetologia 2010, 53, 2496-2503. [CrossRef]

70. Haylett, W.L.; Ferris, W.F. Adipocyte-progenitor cell communication that influences adipogenesis. Cell. Mol. Life Sci. 2020, 77, 115-128. [CrossRef]

71. Gulyaeva, O.; Dempersmier, J.; Sul, H.S. Genetic and epigenetic control of adipose development. Biochim. Biophys. Acta Mol. Cell. Biol. Lipids 2019, 1864, 3-12. [CrossRef]

72. Wenz, T. Regulation of mitochondrial biogenesis and PGC-1 $\alpha$ under cellular stress. Mitochondrion 2013, 13, 134-142. [CrossRef] [PubMed]

73. Nautiyal, J.; Christian, M.; Parker, M.G. Distinct functions for RIP140 in development, inflammation, and metabolism. Trends Endocrinol. Metab. 2013, 24, 451-459. [CrossRef] [PubMed]

74. Nautiyal, J. Transcriptional coregulator RIP140: An essential regulator of physiology. Mol. Endocrinol. 2017, 58, R147-R158. [CrossRef]

75. Leonardsson, G.; Steel, J.H.; Christian, M.; Pocock, V.; Milligan, S.; Bell, J.; So, P.W.; Medina-Gomez, G.; Vidal-Puig, A.; White, R.; et al. Nuclear receptor corepressor RIP140 regulates fat accumulation. Proc. Natl. Acad. Sci. USA 2004, 101, 8437-8442. [CrossRef]

76. Powelka, A.M.; Seth, A.; Virbasius, J.V.; Kiskinis, E.; Nicoloro, S.M.; Guilherme, A.; Tang, X.; Straubhaar, J.; Cherniack, A.D.; Parker, M.G.; et al. Suppression of oxidative metabolism and mitochondrial biogenesis by the transcriptional corepressor RIP140 in mouse adipocytes. J. Clin. Investig. 2006, 116, 125-136. [CrossRef] [PubMed]

77. Kruse, J.P.; Gu, W. Modes of p53 regulation. Cell 2009, 137, 609-622. [CrossRef]

78. Liu, J.; Zhang, C.; Hu, W.; Feng, Z. Tumor suppressor p53 and metabolism. J. Mol. Cell Biol. 2019, 11, 284-292. [CrossRef] [PubMed]

79. Okita, N.; Ishikawa, N.; Mizunoe, Y.; Oku, M.; Nagai, W.; Suzuki, Y.; Matsushima, S.; Mikami, K.; Okado, H.; Sasaki, T.; et al. Inhibitory effect of p53 on mitochondrial content and function during adipogenesis. Biochem. Biophys. Res. Commun. 2014, 446, 91-97. [CrossRef] 
80. Sahin, E.; Colla, S.; Liesa, M.; Moslehi, J.; Müller, F.L.; Guo, M.; Cooper, M.; Kotton, D.; Fabian, A.J.; Walkey, C.; et al. Telomere dysfunction induces metabolic and mitochondrial compromise. Nature 2011, 470, 359-365. [CrossRef]

81. Minamino, T.; Orimo, M.; Shimizu, I.; Kunieda, T.; Yokoyama, M.; Ito, T.; Nojima, A.; Nabetani, A.; Oike, Y.; Matsubara, H.; et al. A crucial role for adipose tissue p53 in the regulation of insulin resistance. Nat. Med. 2009, 15, 1082-1087. [CrossRef]

82. Hallenborg, P.; Fjære, E.; Liaset, B.; Petersen, R.K.; Murano, I.; Sonne, S.B.; Falkerslev, M.; Winther, S.; Jensen, B.A.; Ma, T.; et al. p53 regulates expression of uncoupling protein 1 through binding and repression of PPAR $\gamma$ coactivator- $1 \alpha$. Am. J. Physiol. Endocrinol. Metab. 2016, 310, E116-E128. [CrossRef] [PubMed]

83. Fu, W.; Liu, Y.; Sun, C.; Yin, H. Transient p53 inhibition sensitizes aged white adipose tissue for beige adipocyte recruitment by blocking mitophagy. FASEB J. 2019, 33, 844-856. [CrossRef]

84. Loaeza-Loaeza, J.; Beltran, A.S.; Hernández-Sotelo, D. DNMTs and Impact of CpG Content, Transcription Factors, Consensus Motifs, IncRNAs, and Histone Marks on DNA Methylation. Genes 2020, 11, 1336. [CrossRef] [PubMed]

85. Barrès, R.; Osler, M.E.; Yan, J.; Rune, A.; Fritz, T.; Caidahl, K.; Krook, A.; Zierath, J.R. Non-CpG methylation of the PGC-1alpha promoter through DNMT3B controls mitochondrial density. Cell Metab. 2009, 10, 189-198. [CrossRef] [PubMed]

86. Deng, Y.; Qiu, T.; Zhang, M.; Wu, J.; Zhang, X.; Wang, J.; Chen, K.; Feng, J.; Ha, X.; Xie, J.; et al. High Level of Palmitic Acid Induced Over-Expressed Methyltransferase Inhibits Anti-Inflammation Factor KLF4 Expression in Obese Status. Inflammation 2020, 43, 821-832. [CrossRef]

87. Fan, M.; Rhee, J.; St-Pierre, J.; Handschin, C.; Puigserver, P.; Lin, J.; Jäeger, S.; Erdjument-Bromage, H.; Tempst, P.; Spiegelman, B.M. Suppression of mitochondrial respiration through recruitment of p160 myb binding protein to PGC-1alpha: Modulation by p38 MAPK. Genes Dev. 2004, 18, 278-289. [CrossRef]

88. Shin, J.H.; Ko, H.S.; Kang, H.; Lee, Y.; Lee, Y.I.; Pletinkova, O.; Troconso, J.C.; Dawson, V.L.; Dawson, T.M. PARIS (ZNF746) repression of PGC-1 $\alpha$ contributes to neurodegeneration in Parkinson's disease. Cell 2011, 144, 689-702. [CrossRef] [PubMed]

89. Sergi, D.; Naumovski, N.; Heilbronn, L.K.; Abeywardena, M.; O'Callaghan, N.; Lionetti, L.; Luscombe-Marsh, N. Mitochondrial (Dys)function and Insulin Resistance: From Pathophysiological Molecular Mechanisms to the Impact of Diet. Front. Physiol. 2019, 10, 532. [CrossRef]

90. Okita, N.; Hayashida, Y.; Kojima, Y.; Fukushima, M.; Yuguchi, K.; Mikami, K.; Yamauchi, A.; Watanabe, K.; Noguchi, M.; Nakamura, M.; et al. Differential responses of white adipose tissue and brown adipose tissue to caloric restriction in rats. Mech. Aging Dev. 2012, 133, 255-266. [CrossRef]

91. Linford, N.J.; Beyer, R.P.; Gollahon, K.; Krajcik, R.A.; Malloy, V.L.; Demas, V.; Burmer, G.C.; Rabinovitch, P.S. Transcriptional response to aging and caloric restriction in heart and adipose tissue. Aging Cell 2007, 6, 673-688. [CrossRef]

92. Nisoli, E.; Tonello, C.; Cardile, A.; Cozzi, V.; Bracale, R.; Tedesco, L.; Falcone, S.; Valerio, A.; Cantoni, O.; Clementi, E.; et al. Calorie restriction promotes mitochondrial biogenesis by inducing the expression of eNOS. Science 2005, 310, 314-317. [CrossRef]

93. Pardo, R.; Vilà, M.; Cervela, L.; de Marco, M.; Gama-Pérez, P.; González-Franquesa, A.; Statuto, L.; Vilallonga, R.; Simó, R.; GarciaRoves, P.M.; et al. Calorie restriction prevents diet-induced insulin resistance independently of PGC-1-driven mitochondrial biogenesis in white adipose tissue. FASEB J. 2019, 33, 2343-2358. [CrossRef] [PubMed]

94. Sheng, Y.; Xia, F.; Chen, L.; Lv, Y.; Lv, S.; Yu, J.; Liu, J.; Ding, G. Differential Responses of White Adipose Tissue and Brown Adipose Tissue to Calorie Restriction During Aging. J. Gerontol. A Biol. Sci. Med. Sci. 2021, 76, 393-399. [CrossRef] [PubMed]

95. Giovannini, S.; Carter, C.S.; Leeuwenburgh, C.; Flex, A.; Biscetti, F.; Morgan, D.; Laudisio, A.; Coraci, D.; Maccauro, G.; Zuccalà, G.; et al. Effects of aging and life-long moderate calorie restriction on IL-15 signaling in the rat white adipose tissue. Eur. Rev. Med. Pharmacol. Sci. 2020, 24, 2738-2749. [CrossRef] [PubMed]

96. Derous, D.; Mitchell, S.E.; Green, C.L.; Wang, Y.; Han, J.D.J.; Chen, L.; Promislow, D.E.L.; Lusseau, D.; Douglas, A.; Speakman, J.R. The Effects of Graded Levels of Calorie Restriction: X. Transcriptomic Responses of Epididymal Adipose Tissue. J. Gerontol. A Biol. Sci. Med. Sci. 2018, 73, 279-288. [CrossRef] [PubMed]

97. Wang, J.; Chen, X.; Osland, J.; Gerber, S.J.; Luan, C.; Delfino, K.; Goodwin, L.; Yuan, R. Deletion of Nrip1 Extends Female Mice Longevity, Increases Autophagy, and Delays Cell Senescence. J. Gerontol. A Biol. Sci. Med. Sci. 2018, 73, 882-892. [CrossRef]

98. Anderson, R.; Prolla, T. PGC-1alpha in aging and anti-aging interventions. Biochim. Biophys. Acta 2009, 1790, 1059-1066. [CrossRef] [PubMed]

99. Miller, K.N.; Clark, J.P.; Anderson, R.M. Mitochondrial regulator PGC-1a-Modulating the modulator. Curr. Opin. Endocr. Metab. Res. 2019, 5, 37-44. [CrossRef]

100. Kahn, B.B.; Alquier, T.; Carling, D.; Hardie, D.G. AMP-activated protein kinase: Ancient energy gauge provides clues to modern understanding of metabolism. Cell Metab. 2005, 1, 15-25. [CrossRef]

101. Jäger, S.; Handschin, C.; St-Pierre, J.; Spiegelman, B.M. AMP-activated protein kinase (AMPK) action in skeletal muscle via direct phosphorylation of PGC-1alpha. Proc. Natl. Acad. Sci. USA 2007, 104, 12017-12022. [CrossRef]

102. Garcia-Roves, P.M.; Osler, M.E.; Holmström, M.H.; Zierath, J.R. Gain-of-function R225Q mutation in AMP-activated protein kinase gamma3 subunit increases mitochondrial biogenesis in glycolytic skeletal muscle. J. Biol. Chem. 2008, 283, 35724-35734. [CrossRef]

103. Guarente, L.; Picard, F. Calorie restriction-The SIR2 connection. Cell 2005, 120, 473-482. [CrossRef]

104. Bordone, L.; Guarente, L. Calorie restriction, SIRT1 and metabolism: Understanding longevity. Nat. Rev. Mol. Cell Biol. 2005, 6, 298-305. [CrossRef] [PubMed] 
105. Nemoto, S.; Fergusson, M.M.; Finkel, T. SIRT1 functionally interacts with the metabolic regulator and transcriptional coactivator PGC-1 $\alpha$. J. Biol. Chem. 2005, 280, 16456-16460. [CrossRef]

106. Rodgers, J.T.; Lerin, C.; Haas, W.; Gygi, S.P.; Spiegelman, B.M.; Puigserver, P. Nutrient control of glucose homeostasis through a complex of PGC-1alpha and SIRT1. Nature 2005, 434, 113-118. [CrossRef]

107. Gerhart-Hines, Z.; Rodgers, J.T.; Bare, O.; Lerin, C.; Kim, S.H.; Mostoslavsky, R.; Alt, F.W.; Wu, Z.; Puigserver, P. Metabolic control of muscle mitochondrial function and fatty acid oxidation through SIRT1/PGC-1alpha. EMBO J. 2007, 26, 1913-1923. [CrossRef]

108. Tang, B.L. Sirt1 and the Mitochondria. Mol. Cells 2016, 39, 87-95. [CrossRef]

109. Cantó, C.; Jiang, L.Q.; Deshmukh, A.S.; Mataki, C.; Coste, A.; Lagouge, M.; Zierath, J.R.; Auwerx, J. Interdependence of AMPK and SIRT1 for metabolic adaptation to fasting and exercise in skeletal muscle. Cell Metab. 2010, 11, 213-219. [CrossRef]

110. Iside, C.; Scafuro, M.; Nebbioso, A.; Altucci, L. SIRT1 Activation by Natural Phytochemicals: An Overview. Front. Pharmacol. 2020, 11, 1225. [CrossRef] [PubMed]

111. Svensson, K.; Schnyder, S.; Albert, V.; Cardel, B.; Quagliata, L.; Terracciano, L.M.; Handschin, C. Resveratrol and SRT1720 Elicit Differential Effects in Metabolic Organs and Modulate Systemic Parameters Independently of Skeletal Muscle Peroxisome Proliferator-activated Receptor $\gamma$ Co-activator $1 \alpha$ (PGC-1 $\alpha$ ). J. Biol. Chem. 2015, 290, 16059-16076. [CrossRef] [PubMed]

112. Salazar, J.; Cano, C.; Pérez, J.L.; Castro, A.; Díaz, M.P.; Garrido, B.; Carrasquero, R.; Chacín, M.; Velasco, M.; D’Marco, L.; et al. Role of Dietary Polyphenols in Adipose Tissue Browning: A Narrative Review. Curr. Pharm. Des. 2020, 26, 4444-4460. [CrossRef]

113. Milton-Laskíbar, I.; Gómez-Zorita, S.; Arias, N.; Romo-Miguel, N.; González, M.; Fernández-Quintela, A.; Portillo, M.P. Effects of resveratrol and its derivative pterostilbene on brown adipose tissue thermogenic activation and on white adipose tissue browning process. J. Physiol. Biochem. 2020, 76, 269-278. [CrossRef]

114. Kim, O.Y.; Chung, J.Y.; Song, J. Effect of resveratrol on adipokines and myokines involved in fat browning: Perspectives in healthy weight against obesity. Pharmacol. Res. 2019, 148, 104411. [CrossRef]

115. Fujii, N.; Uta, S.; Kobayashi, M.; Sato, T.; Okita, N.; Higami, Y. Impact of aging and caloric restriction on fibroblast growth factor 21 signaling in rat white adipose tissue. Exp. Gerontol. 2019, 118, 55-64. [CrossRef]

116. Bonkowski, M.S.; Rocha, J.S.; Masternak, M.M.; AI Regaiey, K.A.; Bartke, A. Targeted disruption of growth hormone receptor interferes with the beneficial actions of calorie restriction. Proc. Natl. Acad. Sci. USA 2006, 103, 7901-7905. [CrossRef]

117. Bartke, A.; Wright, J.C.; Mattison, J.A.; Ingram, D.K.; Miller, R.A.; Roth, G.S. Extending the lifespan of long-lived mice. Nature 2001, 414, 412. [CrossRef] [PubMed]

118. Shimokawa, I.; Higami, Y.; Tsuchiya, T.; Otani, H.; Komatsu, T.; Chiba, T.; Yamaza, H. Life span extension by reduction of the growth hormone-insulin-like growth factor-1 axis: Relation to caloric restriction. FASEB J. 2003, 17, 1108-1109. [CrossRef] [PubMed]

119. Chujo, Y.; Fujii, N.; Okita, N.; Konishi, T.; Narita, T.; Yamada, A.; Haruyama, Y.; Tashiro, K.; Chiba, T.; Shimokawa, I.; et al. Caloric restriction-associated remodeling of rat white adipose tissue: Effects on the growth hormone/insulin-like growth factor-1 axis, sterol regulatory element binding protein-1, and macrophage infiltration. Age 2013, 35, 1143-1156. [CrossRef]

120. Kobayashi, M.; Uta, S.; Otsubo, M.; Deguchi, Y.; Tagawa, R.; Mizunoe, Y.; Nakagawa, Y.; Shimano, H.; Higami, Y. Srebp1c/Fgf21/Pgc-1 $\alpha$ Axis Regulated by Leptin Signaling in Adipocytes-Possible Mechanism of Caloric Restriction-Associated Metabolic Remodeling of White Adipose Tissue. Nutrients 2020, 12, 2054. [CrossRef] [PubMed]

121. Kharitonenkov, A.; Adams, A.C. Inventing new medicines: The FGF21 story. Mol. Metab. 2013, 3, 221-229. [CrossRef]

122. Fon Tacer, K.; Bookout, A.L.; Ding, X.; Kurosu, H.; John, G.B.; Wang, L.; Goetz, R.; Mohammadi, M.; Kuro-o, M.; Mangelsdorf, D.J.; et al. Research resource: Comprehensive expression atlas of the fibroblast growth factor system in adult mouse. Mol. Endocrinol. 2010, 24, 2050-2064. [CrossRef] [PubMed]

123. Kilkenny, D.M.; Rocheleau, J.V. The FGF21 Receptor Signaling Complex: Klotho $\beta$, FGFR1c, and Other Regulatory Interactions. Vitam. Horm. 2016, 101, 17-58. [CrossRef]

124. Chau, M.D.; Gao, J.; Yang, Q.; Wu, Z.; Gromada, J. Fibroblast growth factor 21 regulates energy metabolism by activating the AMPK-SIRT1-PGC-1alpha pathway. Proc. Natl. Acad. Sci. USA 2010, 107, 12553-12558. [CrossRef] [PubMed]

125. Véniant, M.M.; Hale, C.; Helmering, J.; Chen, M.M.; Stanislaus, S.; Busby, J.; Vonderfecht, S.; Xu, J.; Lloyd, D.J. FGF21 promotes metabolic homeostasis via white adipose and leptin in mice. PLOS ONE 2012, 7, e40164. [CrossRef] [PubMed]

126. Galinier, A.; Carrière, A.; Fernandez, Y.; Carpéné, C.; André, M.; Caspar-Bauguil, S.; Thouvenot, J.P.; Périquet, B.; Pénicaud, L.; Casteilla, L. Adipose tissue proadipogenic redox changes in obesity. J. Biol. Chem. 2006, 281, 12682-12687. [CrossRef] [PubMed]

127. Frohnert, B.I.; Sinaiko, A.R.; Serrot, F.J.; Foncea, R.E.; Moran, A.; Ikramuddin, S.; Choudry, U.; Bernlohr, D.A. Increased adipose protein carbonylation in human obesity. Obesity 2011, 19, 1735-1741. [CrossRef]

128. Loh, K.; Deng, H.; Fukushima, A.; Cai, X.; Boivin, B.; Galic, S.; Bruce, C.; Shields, B.J.; Skiba, B.; Ooms, L.M.; et al. Reactive oxygen species enhance insulin sensitivity. Cell Metab. 2009, 10, 260-272. [CrossRef]

129. Tormos, K.V.; Anso, E.; Hamanaka, R.B.; Eisenbart, J.; Joseph, J.; Kalyanaraman, B.; Chandel, N.S. Mitochondrial complex III ROS regulate adipocyte differentiation. Cell Metab. 2011, 14, 537-544. [CrossRef]

130. De Mello, A.H.; Costa, A.B.; Engel, J.D.G.; Rezin, G.T. Mitochondrial dysfunction in obesity. Life Sci. 2018, 192, 26-32. [CrossRef]

131. Ungvari, Z.; Tarantini, S.; Donato, A.J.; Galvan, V.; Csiszar, A. Mechanisms of Vascular Aging. Circ. Res. 2018, $123,849-867$. [CrossRef]

132. Bruss, M.D.; Khambatta, C.F.; Ruby, M.A.; Aggarwal, I.; Hellerstein, M.K. Calorie restriction increases fatty acid synthesis and whole body fat oxidation rates. Am. J. Physiol. Endocrinol. Metab. 2010, 298, E108-E116. [CrossRef] 
133. Aksungar, F.B.; Sarıkaya, M.; Coskun, A.; Serteser, M.; Unsal, I. Comparison of Intermittent Fasting Versus Caloric Restriction in Obese Subjects: A Two Year Follow-Up. J. Nutr. Health Aging 2017, 21, 681-685. [CrossRef]

134. Tam, C.S.; Covington, J.D.; Ravussin, E.; Redman, L.M.; Pennington CALERIE Team. Little evidence of systemic and adipose tissue inflammation in overweight individuals. Front. Genet. 2012, 3, 58. [CrossRef] [PubMed]

135. Bussey, C.E.; Withers, S.B.; Aldous, R.G.; Edwards, G.; Heagerty, A.M. Obesity-Related Perivascular Adipose Tissue Damage Is Reversed by Sustained Weight Loss in the Rat. Arterioscler. Thromb. Vasc. Biol. 2016, 36, 1377-1385. [CrossRef]

136. Rodrigues, M.O.M.; Evangelista-Silva, P.H.; Neves, N.N.; Moreno, L.G.; Santos, C.S.; Rocha, K.L.S.; Ottone, V.O.; Batista-da-Silva, B.; Dias-Peixoto, M.F.; Magalhães, F.C.; et al. Caloric restriction-induced weight loss with a high-fat diet does not fully recover visceral adipose tissue inflammation in previously obese C57BL/6 mice. Appl. Physiol. Nutr. Metab. 2020, 45, 1353-1359. [CrossRef] [PubMed]

137. La Russa, D.; Marrone, A.; Mandalà, M.; Macirella, R.; Pellegrino, D. Antioxidant/Anti-Inflammatory Effects of Caloric Restriction in an Aged and Obese Rat Model: The Role of Adiponectin. Biomedicines 2020, 8, 532. [CrossRef] [PubMed]

138. Jeffery, E.; Berry, R.; Church, C.D.; Yu, S.; Shook, B.A.; Horsley, V.; Rosen, E.D.; Rodeheffer, M.S. Characterization of Cre recombinase models for the study of adipose tissue. Adipocyte 2014, 3, 206-211. [CrossRef] [PubMed]

139. Altshuler-Keylinand, S.; Kajimura, S. Mitochondrial homeostasis in adipose tissue remodeling. Sci. Signal. 2017, 10, eaai9248. [CrossRef] 